\title{
Research on Several Problems in Class Management
}

\author{
Ping Li \\ College of Basic Science \\ Tianjin Agricultural University \\ Tianjin 300384, China \\ liping790520@126.com
}

\author{
Zhi-po Zhang \\ School of Law \\ Nankai University \\ Tianjin 300350, China
}

\author{
Chang-tong Yun, Ying Li, De-zhong Ren \\ College of Basic Science \\ Tianjin Agricultural University \\ Tianjin 300384, China
}

\begin{abstract}
To understand the problems in the management of university classes. Intervieus and discussions were used to investigate college students, class cadres and head teachers in applied chemistry. $39.2 \%$ of the students were not interested in the majors they were studying, and they were confused about their professional knowledge. $31.5 \%$ of the students had a weak collective consciousness; $\mathbf{9 0 . 0} \%$ of the head teachers were parttime, and they invested less energy in class management, whose sense of responsibility needed to be strengthened; Some class cadres had poor academic performance, $47.2 \%$ of who had not received scholarships and had weak dedication and spirit of unity and cooperation. Class management is not only the responsibility of head teachers and class cadres, but also the self-management of students. Only three aspects can work together to achieve optimal allocation and efficient use of resources, improve class management efficiency, and create excellent class groups so that every student can benefit from it.
\end{abstract}

Keywords-university; class; collaborative management; improve efficiency

\section{INTRODUCTION}

Class is the most basic unit for the implementation of education and teaching activities in schools, and it is also an important place for college students to study and live. Quality, class style and style of study directly affect the development of each student. Good class atmosphere can enable students to get all-round, comprehensive development, but also conducive to school education and management. College students are a special group. They have just left their parents and joined the collective life in a real sense. They are not mature enough in many aspects, such as social experience, behavior and mental health. In particular, many urban children grow up in a favorable living environment, in most cases; they will be selfcentered and have less collective consciousness. In order to understand the problems existing in the class management of Applied Chemistry Specialty in our college, interviews and discussions were conducted among college students, class cadres and head teachers, and the problems that should be paid attention to in class management were put forward in order to improve the management efficiency and provide a better class atmosphere for the healthy and comprehensive development of students.

\section{PRoblems and CAUSES IN The MANAgement of UNIVERSITY CLASSES}

\section{A. Students'own problems}

In the survey, we found that $94.3 \%$ of college students said that they had been exposed to online games such as "Jesus Survival", "King of Glory" and "League of Legends"; 57.5\% of students had fast-tracking, vibrato and other live webcast software; $30.2 \%$ of students were addicted to online games, especially boys. They even escaped class for playing games and had an indifferent attitude towards the exams. Even the entire dormitory collectively skipped classes, especially in the freshman year. Students who were not addicted to the game used mobile phones for more than 4 hours a day on online chat, browsing entertainment news, and WeChat. After entering the university, many of the students who achieved excellent results in the college entrance examination had a serious decline, and even had a phenomenon of hanging the subject. 39.2\% of the students indicated that they were not interested in the majors they studied, and they were confused about their professional knowledge. The root cause of the above problems was that students did not make reasonable plans for their careers and lack clear goals for their struggles, thus losing their motivation to move forward. Another important reason was that the university's curriculum was more practical and professional. Some students had not mastered the basic knowledge in the middle school period, and had not even touched the chemical experiment, thus becoming self-contemptuous and anxious, so they sought the network to ease and comfort. In addition, the university's learning model was very different from high school. The high school teachers were very strict with students, and the high school life was more depressed. While university teachers will not force the student's attendance rate too much, and even rarely leave homework. Without the examination, the students learn all by themselves. Such a learning model is actually to 
cultivate students' self-learning ability, but some students relax their own requirements, feel bored at ordinary times, begin to get addicted to online games and lack of self-motivation.

In the survey, we also found that $31.5 \%$ of the students treated the collective activities as a burden and a waste of time. They believed that the collective activities were things that the class cadres should attend and had nothing to do with themselves. All of these reflected the students' lack of collective awareness on correctly recognizing the positive significance of participating in group activities. Some students, even if they participated in group activities, were also for signing up. They often adopted a perfunctory attitude and got late when taking part in group activities.

\section{B. Head teacher's problem}

$90.0 \%$ of the head teachers we surveyed were part-time, who must take care of class, research and class management at the same time. In addition to the class, some head teachers put more energy into the scientific research. Teachers thought that as long as the students were strictly required without any accidents according to the school's rules and regulations, the task of the class management was completed. In fact, in conversations with many college students, we found that the number of times a student could see the head teacher every semester was limited, usually at the beginning of the school and at the end of the period. Some students didn't even know the name of their head teacher. All these indicated that the head teacher had invested little energy in class management. Regarding some of the school's notices and activities, they often let the class cadres organize the implementation or notified the students in the QQ group, and rarely hold face-toface class meetings. $61.2 \%$ of the head teacher could not guarantee to talk with each student at least once per semester, $71.0 \%$ of the head teacher could not guarantee to communicate with each teacher once a year and $85.0 \%$ of the head teacher could not guarantee to contact parent of each student once a year.

\section{Class cadres'problem}

In the survey of 12 class cadres, we found that the class with good performance and various activities often had a team of cadres with strong unity and ability. On the contrary, in some poor grades, the class cadres themselves had poor academic performance. $47.2 \%$ of the class cadres did not receive scholarships, and their authority in the class was weak. Some class activities, such as appraisal of advanced class groups, civilized dormitory appraisal, and evaluation of advanced community organizations, could not be carried out. They often chose to give up and gave opportunities to other classes. Over time, the enthusiasm of the class cadres would be lost, and the enthusiasm of class students would also be greatly affected. Some class cadres thought of themselves firstly when encountering opportunities, such as joining the party, advanced individuals in social practice, and good students. They thought that they paid a lot for the class, and of course they should get a lot. In addition, there were also "small gangs" in some class cadres, lacking the spirit of solidarity and cooperation.

\section{SEVERAL PROBLEMS SHOULD BE PAID ATTENTION TO IN} CLASS MANAGEMENT

In view of the problems in class management, the author raised the problems that should be paid attention to from the three aspects of students, head teachers and class cadres, so as to improve the efficiency of class management, create a good class atmosphere, and provide a better class environment for students' comprehensive and healthy development.

\section{A. Problems that students should pay attention to}

Students should correctly understand and evaluate themselves, make reasonable plans for their study, life and career and put them into practical action, learn to selfmanagement, and make steady progress [1]. In addition, college students should actively participate in social practice and second classroom activities, fully understand the society, learn to establish a sense of responsibility, objectively and correctly understand themselves, correct their position, and see the gap between their own capabilities and market demand through social practice and make better efforts to make up for deficiencies[2]. The second classroom activities, such as the participation of college students in innovation and entrepreneurship projects, can improve students' professional skills, cultivate scientific research literacy, enhance team spirit and improve innovation ability. In short, the development of students themselves is also an important form of contribution to the management of the whole class. In addition, students should actively contribute to class activities according to their strengths.

\section{B. Problems that head teachers should payattention to}

Head teachers are the backbone of moral education in colleges and universities and guide of the healthy development of college students. They play the most crucial role in class management. A good head teacher should have the correct political direction, profound knowledge and strong working ability, high sense of responsibility and dedication. Head teachers should keep in mind the duty in charge of a class, that is, do a good job in daily basic work of the class, guide students to study and grow healthily, carry out regular ideological and political education activities to help students to establish a firm and correct political direction and correct world outlook, outlook on life, values, do a good job in the construction of the class style and study style, establish a good style of diligence, caring for the collective, solidarity, friendship, hardship and simplicity, abide by the laws and regulations in the class, grasp the students' dynamic in time, listen to the students' opinions and requirements and safeguard legitimate interests of the students. In addition, head teachers can't always overemphasize the collective interests of the class above everything since if reasonable individual interests can't be satisfied for a long time, enthusiasm and creativity of students and competitiveness and advantages of the whole class will be inevitably affected.

The weekly conversation system should be established. Head teachers should understand the problems that students encounter in their study and life, listen to their voices and treat each student fairly. If head teachers can try their best to help the students solve problems, the students will also feel the 
teacher's help to themselves, and naturally they will study hard, which will bring more bright spots for class construction. In addition, competition mechanism should be introduced into the class. Through competition, classes can form a positive atmosphere of "comparison, study, catching up, helping, and exceeding", stimulating each student's maximum potential and enthusiasm to participate in class management, so as to achieve the optimal allocation of class resources, which is also of great benefit to the development of students themselves.

The communication platform between professional teachers and students should be actively built[3-4]. Many professional teachers have scientific research topics, most of whom work in the scientific research field for a long time, and have high professional quality and scientific research innovation skills. Professional teachers can indirectly assist head teachers in training students through the guidance of students' innovation and entrepreneurship projects, subject competitions and graduation thesis. In daily life, teaching and scientific research work, professional teachers' ethics, academic level and guidance will play a subtle role for students. Students' direct participation in the subject research of professional teachers is beneficial to exerting students' subjective initiative, arousing their enthusiasm to participate in scientific research and innovation activities, cultivating professional quality and improving professional skills, which are sometimes better than head teachers' language teaching.

\section{Problems that class cadres should pay attention to}

Class cadre is an important bridge for students to contact directly with head teachers. The behavior of class cadres will directly affect the mental outlook of students in the whole class. A group of class cadres with strong ability and high prestige can help the head teacher to manage the class and achieve twice the result with half the effort. Class cadres devote a lot of energy to class affairs, especially those in the lower grades, who are relatively unfamiliar with class affairs. If they have poor self-control and can't manage their time scientifically, they will inevitably affect their academic performance and their authority in the class will also be affected. Finally, their enthusiasm for class management declined and even came into conflict. Facing this kind of situation, head teacher should pay more attention to their study, help them use scientific learning methods to improve their grades, master appropriate working methods and communication art, fully trust class cadres, let them deal with problems independently according to the requirements of the school, and stimulate potential leadership. In addition, class cadres should first do what they want students to do. They should try their best to be the model of the class students in their study and life, cooperate with each other, establish prestige among the students, drive the class to form a centripetal force and cohesion, and inspire everyone who lives in the class.

It should be emphasized that the development of things is affected by many factors, and cooperation is particularly important[5-6]. Class management is not a unilateral act managed by head teachers, class cadres or students themselves. It is indispensable to establish a cooperative mechanism of the three in order to create an excellent class, so that every student can benefit from it.

\section{CONCLUSION}

In short, the quality of class management, class atmosphere and style of study directly affect the development of each student. Good class atmosphere can enable students to get allround, comprehensive development, but also is conducive to school education and management. Class management is not only the responsibility of head teachers and class cadres, students themselves should first learn to self-management, to establish a student-head teacher-class cadres "three-in-one" management mechanism. Only in this way can we maximize the optimal allocation and efficient use of class resources, create a positive class atmosphere, let each student feel the warmth of the class, and enhance the sense of collective honor of the class.

\section{ACKNOWLEDGMENT}

I would like to thank the Tianjin Agricultural College's Teacher Education Reform and Innovation and Development Project (20170817) for the fund support of this paper.

\section{REFERENCES}

[1] D. R. Reineckea, A. Krokowskib, and B. Newman, Self-management for building independence: research and future directions, International Journal of Educational Research, 2018, vol. 87, pp.119-126.

[2] V. M. Smokotina, G. I. Petrovab, and S. K. Gural, Theoretical principles for knowledge management in the research university, Procedia-Social and Behavioral Sciences, 2014, vol. 154, pp. 229-232.

[3] R. Bakar, The influence of professional teachers on padang vocational school students' achievement, Kasetsart Journal of Social Sciences, 2018, vol. 39, pp. 67-72.

[4] T. F. Tengku Ariffin, T. Bush, and H. Nordin, Framing the roles and responsibilities of excellent teachers: evidence from Malaysia, Teaching and Teacher Education, 2018, vol. 73, pp. 14-23.

[5] M. Misic, Collaborative management of technological resources at northern Illinois university, Techtrends, 1995, vol. 40, pp. 15-18.

[6] D. D. Paulson, Collaborative management of public rangeland in wyoming: lessons in co-management, 1998, Professional Geographer, vol. 50, pp. 301-315. 